\title{
コンクリート系製品を用いた河川護岸構造物の 景観設計に関する基礎的研究
}

\author{
村田 茂樹*1 ・岡本 享久 ${ }^{* 2} \cdot$ 鳥居南康一 $* 3 \cdot$ 仕入 豊和*4
}

\begin{abstract}
概 要 本研究は, 河川護岸構造物を対象として, 現在多用されている石積みブロック，間知ブロックあるいは緑化ブロッ ク等のコンクリート系製品を取り上げて, 周辺環境に調和したコンクリート系製品の開発に際しての基本的指針を得ることを 目的として次のことを行った。すなわち, 製品の表面性状の違いに加え, 製品までの視距離および背景の相違等が人間の評価 心理に及ぼす影響を SD 法 (Semantic Differential 法) による官能検査によって評価し，この種製品の景観設計に関する基 礎資料を求めたものである。

キーワード : コンクリート構造物, 河川護岸構造物, コンクリート系製品, 景観評価, 表面テクスチャー, 色, 背景, 景観 設計法
\end{abstract}

\section{1.はじめに}

筆者は，コンクリート構造物の景観評価に際し，人間 が受ける印象（評価心理構造）と構造物に多用されてい るコンクリート製品の表面性状との相関性を感性工学的 に考察を加えてきている1),2)。しかしながら，製品自 体の表面性状以外に，視点場之構造物の位置関係，た之 えば視点場と構造物までの距離の影響, 構造物を真正面 に見るか, 斜め方向から見るかという視点場の位置関係 の影響, さらには構造物の背景に存在する山, 建築物お よび樹木の影響等も，景観評価の際考慮しなければなら ない重要な影響要因である。特に背景の問題は，構造物 の景観評価に際し重要であるにも関わらず，背景の定量 化が難しいことが原因となり，この種の研究例は少な い。

最近，近自然工法が叫ばれ，河川環境の形成に対応が 可能で，かつ流水などに対して強固な護岸を構築できる コンクリート系製品の設計が行われるようになりつつあ る。そこで本研究では河川護岸を対象として，そこで用 いられるコンクリート系製品の表面性状の相違, 製品表 面から視点までの距離および背景の違いが, 評価心理構 造に及ぼす影響を SD 法による官能検査で解析した。続 いて，製品の表面性状の相違として，凹凸の度合い，明 度，彩度および表面テクスチャーを取り上げ，構造物の

* 1 日本イトン工業株研究所（正会員）

*2 日本セメント(侏)中央研究所 主席研究員 (正会員)

*3 日本セメント株中央研究所（正会員）

*4 神奈川大学教授 工学部建築学科（正会員)
背景として樹木を中心とした緑とコンクリート系構造物 を取り上げて，これらの影響因子の定量化を試みた。こ れらの影響因子と官能検查結果との相関性を明らかにし て, この種製品の景観設計確立のための基礎資料を得る ことを目的としたものである。

2. 景観評価に及ぼすコンクリート系製品 の表面性状の影響

\section{1 実験および解析の概要}

（1） サンプルおよび官能検査方法

評価対象はコンクリート系製品を用いた河川護岸構造 物とした。既往の研究 ${ }^{3)}$ で, 気象条件および計測時間を 同一の条件とした場合，写真サンプルを用いた官能検査 結果と実際の構造物に対して実施した官能検查結果の相 関性は大変高く,これらの間には差が無いことが確かめ られたので，官能検查には写真サンプルを用いることと した。検査に用いた製品は，写真一1および表-1に示す ように表面性状の異なるコンクリート製品 10 種類を用 意した。

これらを以下に示す距離別に撮影した 4 グループのサ ンプル 40 種類を作って検査を行った。各グループの基 本構図は写真-2 に示すとおりである。

Aグループ : 製品自体の素材の表面性状が十分確認で きる約 $3 \mathrm{~m}$ 10 $\mathrm{m}$ の距離で撮影したも の。

Bグループ: 対象までの距離約 $20 \mathrm{~m}$ で撮影したも の。

Cグループ : 対象までの距離約 $90 \mathrm{~m}$ で撮影したも 
の。

Dグループ: 対象までの距離約 $180 \mathrm{~m}$ で撮影したも の。

なお $\mathrm{B}, \mathrm{C}$ および D グループでは, 評価対象とした 護岸構造物の指定箇所に, コンピュータグラフィクス (以下 CG) を用いて，写真-1で示す各サンプルをマッ チングさせて合成写真を作成した。官能検査は, 被験者 を理工系の大学生, 主婦およびセメント・コンクリート 関係に携わっている59人（男：35名, 女：24名）上し 表-2 に示す形容詞 14 対について SD 法による 5 段階尺 度で，写真サンプルの護岸構造物に対し行った。

なお, SD 法とは, Semantic Differential 法の略 で, 官能検査, 特に嗜好型の官能検査においてイメージ の有力な計量手段として用いられている。

(2) 製品の物理量の測定

景観構成要素である製品の表面性状を示す物理量とし て色彩，表面凹凸度および表面テクスチャーを測定し た。色彩は色彩色差計を用いて, 写真から $L^{*} a^{*} b *$ 表色 系により明度 $(L)$, 彩度 $\left(\sqrt{a^{2}+b^{2}}\right)$ を測定した。表面 凹凸は, 高さ $30 \mathrm{~cm}$ の脚部之長さ $1 \mathrm{~m}$ の梁部からなる 測定器具により測定し, この器具を測定対象のサンプル にセットして, 梁部とサンプル表面の読みの最大值と最

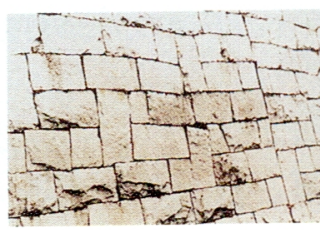

(c)

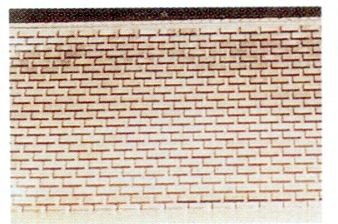

$(\mathrm{g})$

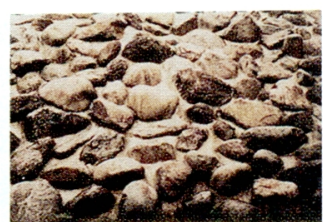

(d)

不積み 3 種

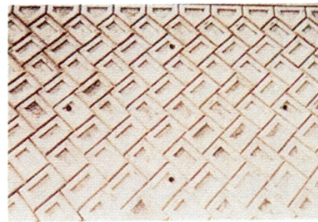

( h )

コンクリート間知ブロック 3 種

写真-1 官能検査に用いたサンプルの表面性状

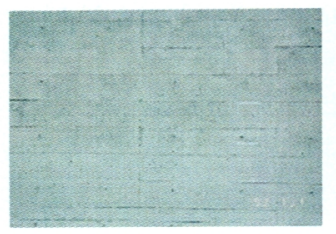

$\mathrm{A}$ グループ

(視距離 $=3 \sim 10 \mathrm{~m}$ )

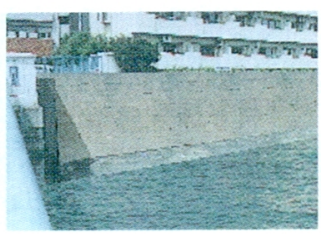

$\mathrm{B}$ グループ

(視距離 $=20 \mathrm{~m}$ )

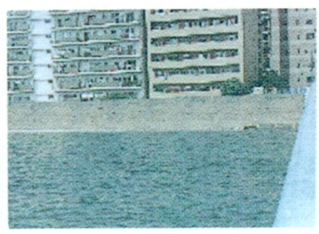

$\mathrm{C}$ グループ

(視距離 $=90 \mathrm{~m}$ )

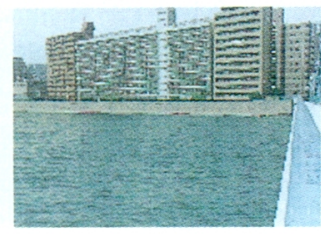

$\mathrm{D}$ グループ

(視距離 $=180 \mathrm{~m}$ )

写真-2 官能検査に用いた写真サンプルの基本構図 
表一1 検査に用いた材料

\begin{tabular}{|c|c|c|c|c|}
\hline & 材 料 名 & $L$ & $C$ & $\begin{array}{l}\text { 最 大 } \\
\text { 四凸度 } \\
(\mathrm{mm})\end{array}$ \\
\hline (a) & 緑化ブロック I & 61.31 & 6.24 & - \\
\hline (b) & 緑化ブロック II & 68.55 & 13.14 & - \\
\hline (c) & 石積みブロック & 60.44 & 2.73 & 32.73 \\
\hline (d) & 大型石積みブロック & 56.17 & 4.64 & 158.00 \\
\hline (e) & 石積みモルタル & 64.80 & 10.07 & 61.63 \\
\hline (f) & 打ち放しコンクリート & 63.71 & 5.36 & 6.95 \\
\hline$(\mathrm{g})$ & コンクリート間知ブロック I & 58.98 & 17.62 & - \\
\hline$(\mathrm{h})$ & コンクリート間知ブロック II & 68.58 & 13.21 & 1.00 \\
\hline (i ) & コンクリート間知プロック III & 48.03 & 18.06 & 13.40 \\
\hline$(\mathrm{j})$ & 着色急結モルタル（茶系） & 67.19 & 3.84 & 57.0 \\
\hline
\end{tabular}

（注） $L:$ 明度, $C:$ 彩度 $\left(=\sqrt{a^{2}+b^{2}}\right)$

表一3 主成分分析結果 ( $\mathrm{A}$ グループ: $3 \mathrm{~m} \sim 10 \mathrm{~m}$ )

\begin{tabular}{|c|c|c|c|}
\hline 容 & 第 1 主成分 & 第 2 主成分 & 第 3 主成分 \\
\hline 暖かいー冷たい & 0.980 & 0.049 & -0.071 \\
\hline 自然的な一人工的な & 0.963 & -0.241 & -0.035 \\
\hline 潤いのある一乾いている & 0.955 & 0.129 & -0.232 \\
\hline やすらぎのある－落ち着きのない & 0.942 & 0.232 & 0.044 \\
\hline 色彩に富んだ-色彩にそしい & 0.921 & 0.315 & -0.161 \\
\hline 都会的な一田舎風な & -0.857 & 0.490 & -0.132 \\
\hline 整然としたー雑然とした & -0.844 & 0.478 & -0.156 \\
\hline 親しみのあるーよそよそしい & 0.791 & 0.437 & 0.152 \\
\hline 単純なー複雑な & -0.782 & 0.282 & -0.466 \\
\hline 調和したー調和しない & 0.719 & 0.535 & 0.151 \\
\hline 新しいー古い & 0.169 & 0.955 & 0.136 \\
\hline きれいー污い & 0.044 & 0.920 & -0.214 \\
\hline 目立っているー目立ってない & 0.146 & 0.628 & -0.607 \\
\hline 大きいー小さい & -0.116 & -0.078 & 0.766 \\
\hline 寄 与 率 $(\%)$ & 72.6 & 16.7 & 5.2 \\
\hline 累積寄与率 (\%) & 72.6 & 89.3 & 94.4 \\
\hline
\end{tabular}

表-5 主成分分析結果 (C グループ: $90 \mathrm{~m}$ )

\begin{tabular}{|c|c|c|c|}
\hline 形容詞 & 第 1 主成分 & 第 2 主成分 & 第 3 主成分 \\
\hline 暖かいー冷たい & 0.988 & 0.095 & 0.040 \\
\hline 潤いのあるー乾いている & 0.971 & -0.075 & -0.057 \\
\hline 色彩に富んだー色彩にそしい & 0.961 & 0.217 & 0.106 \\
\hline 親しみのあるーよそよそしい & 0.945 & 0.204 & 0.074 \\
\hline 自然的な - 人工的な & 0.935 & -0.248 & 0.029 \\
\hline やすらぎのある - 落ち着きのない & 0.859 & 0.390 & 0.014 \\
\hline 単純なー複雑な & -0.729 & -0.107 & 0.466 \\
\hline 都会的な一田舎風な & -0.710 & 0.685 & -0.029 \\
\hline 目立っている一目立ってない & 0.679 & -0.147 & 0.181 \\
\hline きれいー污い & 0.213 & 0.925 & 0.204 \\
\hline 調和したー調和しない & 0.171 & 0.878 & -0.103 \\
\hline 新しいー古い & 0.517 & 0.792 & 0.019 \\
\hline 整然とした－雑然とした & -0.662 & 0.698 & -0.087 \\
\hline 大きいー小さい & -0.415 & -0.413 & 0.666 \\
\hline 寄 与 率 $(\%)$ & 62.5 & 25.4 & 3.3 \\
\hline 累積寄与率 (\%) & 62.5 & 87.9 & 91.2 \\
\hline
\end{tabular}

\section{表-2 検查に用いた形容詞群}

\begin{tabular}{|c|c|c|c|}
\hline & 形 & 詞 & 群 \\
\hline 1. & \multicolumn{3}{|c|}{ 自然的な一人工的な } \\
\hline 2. & \multicolumn{3}{|c|}{ 整然としたー雑然とした } \\
\hline 3. & \multicolumn{3}{|c|}{ きれいー污い } \\
\hline 4. & \multicolumn{3}{|c|}{ 色彩に富んだー色彩にそしい } \\
\hline 5. & \multicolumn{3}{|c|}{ 大きいー小さい } \\
\hline 6. & \multicolumn{3}{|c|}{ 潤いのあるー乾いている } \\
\hline 7. & \multicolumn{3}{|c|}{ 親しみのあるーよそよそしい } \\
\hline 8. & \multicolumn{3}{|c|}{ やすらぎのあるー落ち着きのない } \\
\hline 9 . & \multicolumn{3}{|c|}{ 都会的な-田舎風な } \\
\hline 10 . & \multicolumn{3}{|c|}{ 単純な一複雑な } \\
\hline 11. & \multicolumn{3}{|c|}{ 目立っているー目立っていない } \\
\hline 12 . & \multicolumn{3}{|c|}{ 暖かいー冷たい } \\
\hline 13. & \multicolumn{3}{|c|}{ 新しいー古い } \\
\hline 14. & \multicolumn{3}{|c|}{ 調和した一調和しない } \\
\hline
\end{tabular}

表-4 主成分分析結果 (B グループ $20 \mathrm{~m}$ )

\begin{tabular}{|c|c|c|c|}
\hline 形 容 詞 & 第 1 主成分 & 第 2 主成分 & 第 3 主成分 \\
\hline 暖かいー冷たい & 0.974 & 0.156 & -0.110 \\
\hline 自然的な一人工的な & 0.970 & -0.169 & -0.093 \\
\hline 色彩に富んだー色彩にそしい & 0.924 & 0.305 & -0.081 \\
\hline 潤いのあるー乾いている & 0.912 & -0.314 & -0.227 \\
\hline やすらぎのある－落ち着きのない & 0.888 & 0.384 & -0.112 \\
\hline 親しみのあるーよそよそしい & 0.808 & -0.435 & 0.047 \\
\hline 都会的な-田舎風な & -0.797 & 0.571 & -0.089 \\
\hline 単純なー複雑な & -0.776 & -0.294 & -0.419 \\
\hline 新しいー古い & 0.385 & 0.864 & 0.184 \\
\hline きれいー污い & 0.415 & 0.854 & 0.179 \\
\hline 調和したー調和しない & 0.507 & 0.762 & -0.322 \\
\hline 整然としたー雑然とした & -0.637 & 0.705 & -0.266 \\
\hline 大きいー小さい & -0.428 & -0.587 & 0.380 \\
\hline 目立っているー目立ってない & 0.386 & -0.057 & 0.826 \\
\hline 寄 与 率 $(\%)$ & 62.5 & 25.6 & 5.9 \\
\hline 累積寄与率 (\%) & 62.5 & 88.0 & 94.0 \\
\hline
\end{tabular}

表-6 主成分分析結果 (D グループ: $180 \mathrm{~m}$ )

\begin{tabular}{|c|c|c|c|c|}
\hline 形容詞 & $\begin{array}{l}\text { 第 } 1 \\
\text { 主成分 }\end{array}$ & $\begin{array}{l}\text { 第 } 2 \\
\text { 主成分 }\end{array}$ & $\begin{array}{l}\text { 第 } 3 \\
\text { 主成分 }\end{array}$ & $\begin{array}{l}\text { 第 }{ }^{4} \\
\text { 主成分 }\end{array}$ \\
\hline 暖かいー冷たい & 0.980 & -0.053 & -0.051 & -0.072 \\
\hline 親しみのあるーよそよそしい & 0.974 & -0.046 & -0.054 & 0.139 \\
\hline 色彩に富んだー色彩に乏しい & 0.972 & 0.117 & 0.065 & 0.011 \\
\hline やすらぎのあるー落ち着きのない & 0.954 & -0.222 & 0.023 & 0.017 \\
\hline 自然的な一人工的な & 0.942 & 0.114 & 0.062 & 0.160 \\
\hline 都会的なー田舎風な & 0.934 & -0.314 & 0.125 & 0.032 \\
\hline 整然とした一雑然とした & -0.659 & 0.506 & -0.491 & 0.023 \\
\hline 潤いのあるー乾いている & -0.527 & 0.490 & 0.384 & 0.471 \\
\hline 新しい一古い & 0.452 & 0.863 & 0.057 & -0.186 \\
\hline きれいー污い & 0.612 & 0.739 & 0.236 & 0.082 \\
\hline 大きいー小さい & -0.394 & 0.031 & 0.711 & -0.344 \\
\hline 単純な一複雑な & -0.652 & -0.198 & 0.676 & 0.150 \\
\hline 目立っているー目立ってない & 0.482 & 0.229 & -0.416 & 0.689 \\
\hline 調和したー調和しない & 0.368 & 0.553 & 0.368 & -0.608 \\
\hline 寄 与 率 (\%) & 65.8 & 16.1 & 8.9 & 4.9 \\
\hline 累積寄与率 (\%) & 65.8 & 81.9 & 90.7 & 95.6 \\
\hline
\end{tabular}


表-7 各主成分の持つ意味（製品表面から視点までの距離の 及ぼす影響)

\begin{tabular}{c|c|c|c|c|c|c}
\hline \multirow{2}{*}{$\begin{array}{c}\text { 写真グ } \\
\text { 視距離 } \\
(\mathrm{m})\end{array}$} & \multicolumn{5}{|c}{ 主 成 分 の 意 味 } \\
\cline { 3 - 7 } & & 第1主成分 & 第 2主成分 & 累積寄与率 & 第 3 主成分 & 第 4 主成分 \\
\hline $\mathrm{A}$ & $3 \sim 10$ & 暖かさ & 新しさ & 89.3 & 大小 & - \\
\hline $\mathrm{B}$ & 20 & 暖かさ & 新しさ & 88.0 & 調和 & - \\
\hline $\mathrm{C}$ & 90 & 暖かさ & 新しさ & 87.9 & 大小 & - \\
\hline $\mathrm{D}$ & 180 & 暖かさ & 新しさ & 81.9 & 大小 & 調和 \\
\hline
\end{tabular}

れている。 $\mathrm{A}, \mathrm{B}, \mathrm{C}$ および D グループの相違，すなわ ち視距離の相違によらず，第 1 主成分は『暖かさの感 覚』および第 2 主成分は『新しさの感覚』として景観評 価心理が表現されている。第 2 主成分までの累積寄与率 が $80 \%$ 以上の值となっていることから，この種の構造 物の景観評価心理に関してはこれら 2 つの主成分の影響 が大きく，これらの主成分で景観評価心理構造の概略の 説明が可能と考えられた。なお，その他にこれらの評価 心理構造は, 被験者の職種, 年齢および性別の違いによ る影響も受けなかったことが大きな特徴であった5)。

（2）コンクリート系製品の表面の物理量が景観評価 に及ぼす影響

1）色彩が景観評価に及ぼす影響

図-1に写真 B グループにつ いて彩度と第 1 主成分得点の関 係を示す。なお, 物理量の表示 は「感覚は刺激の対数に比例す る」という Weber-Fechner 則 ${ }^{6)}$ を参考にした。彩度が高く なる之, 第 1 主成分すなわち 『暖かさの感覚』が高くなる傾 向が認められた。これは, 素材 表面に自然石や緑を用いある程 度彩度が高い方が [暖かい] と 感じることを示している。しか し, 明度亡第 1 主成分の関係に は, 相関係数 0.5 以上の相関が 見られなかった。

図-2に写真 B グループにつ いて明度と第 2 主成分得点の関 係を示す。明度が高くなると, 第 2 主成分すなわち『新しさの 感覚』が高くなる傾向が認めら れた。これは, 素材表面の明度 が高く, 明るい印象を受ける場 合ほど [新しい] と感じること を示すものと考えられた。

2）表面の凹凸度が景観評価

\section{に及ぼす影響}

図-3に写真 B グループについて最大山凸度と第 1 主 成分得点の関係を示す。最大凹凸度が大きくなると，第 1 主成分『暖かさの感覚』が高くなる傾向が認められ る。これは, 表面に凹凸がある方が自然物に近く感じ, その結果『暖かさの感覚』に対して影響を及ぼしている と考えられた。

3）表面テクスチャーが景観評価に及ぼす影響

図-4に写真 B グループについて表面の 2 次モーメン 卜と第 1 主成分得点の関係を示す。表面テクスチャーを 数值化した 2 次モーメントが小さくなるほど（值が $0 に$ 近(ほどテクスチャーが複雑であることを示す), 第 1 主成分『暖かさの感覚』が高くなる傾向が認められる。 これは, 表面テクスチャーが複雑な場合に製品から自然 な感じを受け，その結果『暖かさの感覚』に対して影響 を及ぼしているためと思われた。

3. 景観評価に及ぼす構造物の背景の影響

\section{1 実験および解析の概要}

（1）官能検查に用いたサンプル

サンプルは背景を建築物, 樹木およびそれらが混在す る場合の 3 パターンとなるように写真を合成した。背景

(樶かい)

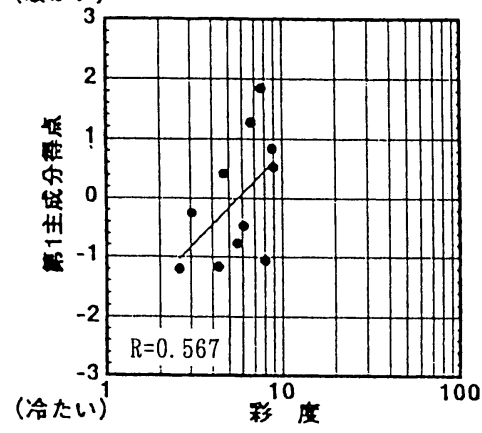

図-1 彩度と第 1 主成分得点との関係 (写真 B)

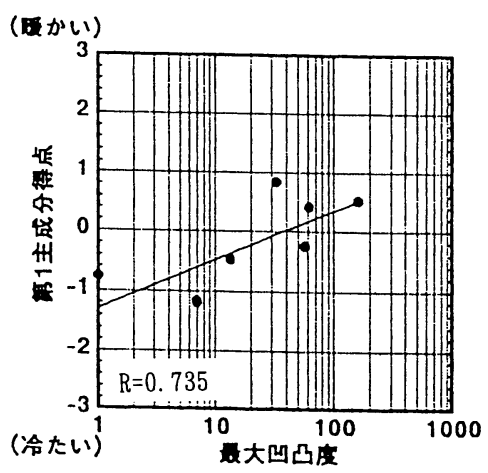

図-3 最大凹凸度と第 1 主成分得点との関 係 (写真 B)

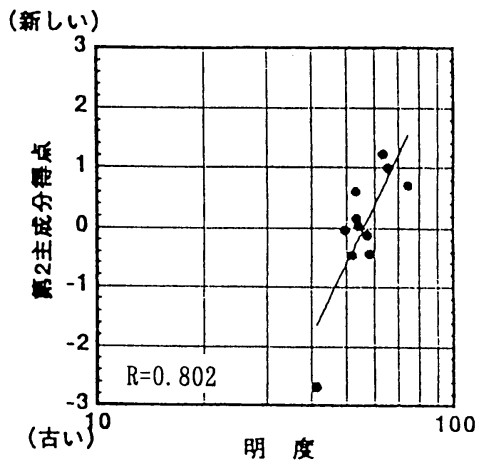

図-2 明度と第 2 主成分得点との関係 (写真 B)

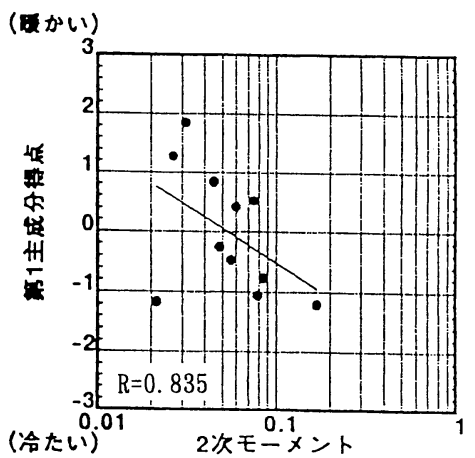

図-4 2 次モーメントと第 1 主成分得点との 関係 (写真 B) 
の要因としてはその他に，樹木の面積率，樹木の見え方 および建築物の面積率を取り上げそれらの効果を検討し た。今回は, 視点から対象物までの距離を C グループ $(90 \mathrm{~m})$ の背景を含めた護岸構造物の写真を作成した。 護岸構造物を構成する製品の表面性状として, 表-1の 中から石積み, 緑化ブロックおよびコンクリートブロッ クの 3 種類の製品を選定した。

(2) 官能検查方法

背景が樹木のみの場合は, 対象写真に占める背景部分 に対する樹木の面積率および樹木の見え方を変化させた 5 種類, 背景が建築物のみの場合は, 対象写真に占める 背景部分の面積に対する建築物の面積率を変化させた 6 種類, さらにこれらを混合させた場合の 9 種類の背景を 設定し, 背景の異なる総計 20 種類の合成写真を作成し た。

表 -2 に示す形容詞群に, 風景のこと7)を考虑した形 容詞群「開放感のある一圧迫感のある」「馴染んでいる 一馴染んでいない」,「すがすがしいーうっとうしい」, 「穏やかな一荒々しい」,「やすらぎのある一落ち着きのな い」を加え, 合計 19 組の形容詞を用いて 60 枚の写真サ
ンプルについて官能検查を実施した。

（3）物理量の測定一背景に占める樹木並びに建築物 の面積率一

写真 -3 に示すように写真内の背景部分, すなわち護 岸より上の部分の面積に対する緑化面積および建築物の 面積の割合を画像処理装置によって測定し, それぞれ緑 化面積率および建築物面積率とした。これらが護岸構造 物の製品とからめた景観評価にどの程度影響するかを調 べた。なお,これらの面積率は $\mathrm{CG}$ を用いて変化させ た。

\section{2 結果および考察}

19 組の形容詞対ごとに $2 \sim-2$ の 5 段階で点数付け し, 官能検查に用いたサンプルについて評価平均点を求 めた。これらの評価平均点を用い, 景観構成要素である 製品および背景のそれぞれの物理量との関倸について検 討を行った。

製品の表面性状に関する物理量の $L$ (明度)，C (彩 度）および表面の 2 次モーメントと背景の面積率につい て，2.で示した第 1 主成分の各形容詞対「暖かい一冷た い」との相関図を作成し, 図-5, 図-6および図-7に示

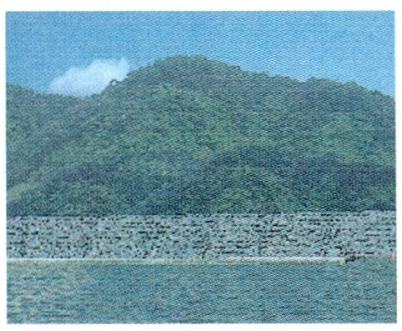

樹木のみ

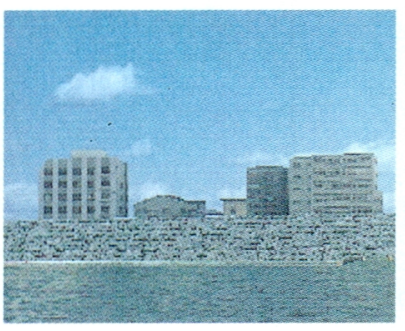

建築物のみ

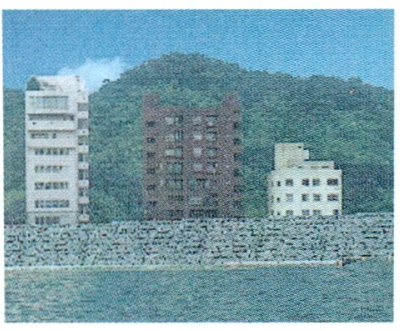

樹木および建築物が混在

写真-3 官能検査に用いた写真サンプル例
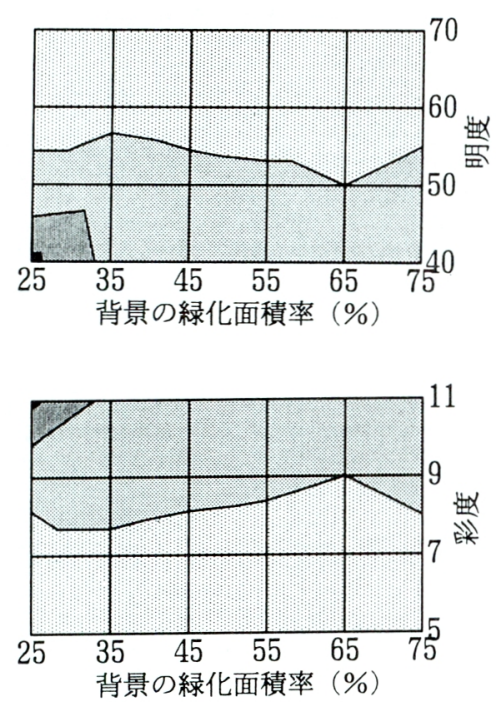

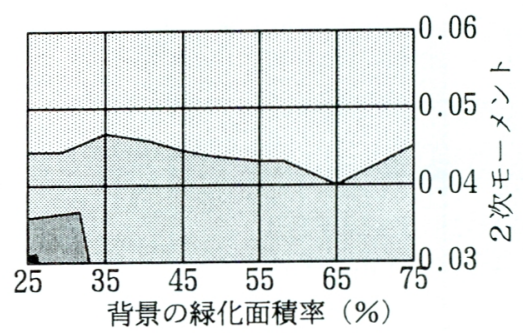

平均得点

1.5-2 第 1 主成分（暖加小、自然的）

님 $1-1.5$

$0.5-1$

四0-0.5 第 1 主成分（冷たい、人工的）

図-5 背景の樹木の面積率, 製品の表面性状に関する物理量との景観評価間の相関図（背景が樹木のみ） 
す。

\section{（1）背景が樹木のみの場合}

景観評価における「暖かい一冷たい」に，背景に占め る樹木の割合 (緑化面積率) および製品の表面性状 (明 度, 彩度あるいは表面の 2 次モーメント）が及ぼす影響 を図-5 に示す。第 1 主成分に関する景観評価は, 背景 の緑化面積率が小さいと, 製品の明度, 彩度および表面 の 2 次モーメントの影響を受けやすいことがわかる。す なわち, 背景に樹木など緑の部分が少量存在する場合に は，製品の選択の場合に製品の明度を低く，彩度を高く
さらに表面の 2 次モーメントを小さくする工夫を行うこ とにより, 第 1 主成分である [暖かさ, 自然的］を強調 する景観となった。

（2）背景が建築物のみの場合

図-6 は同様に，第 1 主成分に及ぼす背景に占める建 築物の割合（建築物の面積率）の影響を製品の表面性状 別に示すものである。背景が樹木の場合と比べて, 景観 評価が複雑となり, 背景に占める建築物の面積が大きい 場合, 製品の明度, 彩度あるいは表面の 2 次モーメント を変化させても [暖かさ, 自然的］を強調することが極
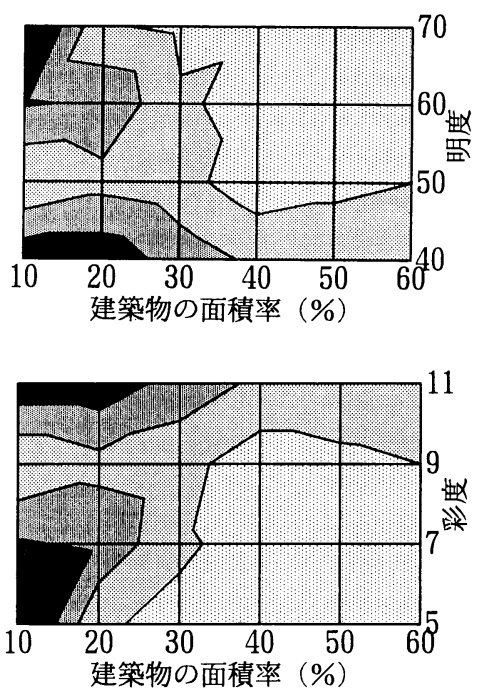

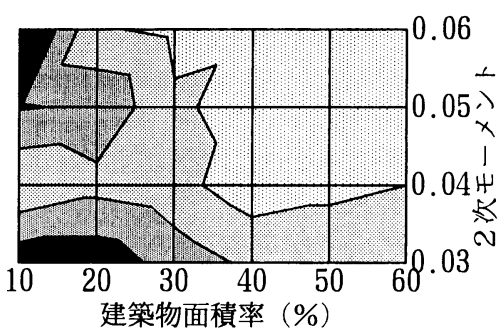

平均得点

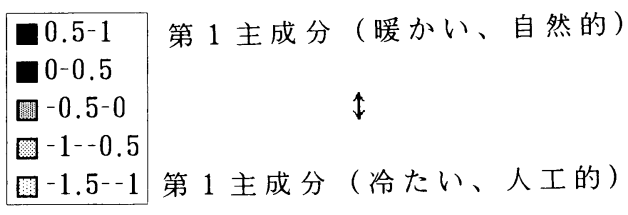

図-6 背景の建築物の面積率，製品の表面性状に関する物理量と景観評価間の相関図（背景が建築物のみ）

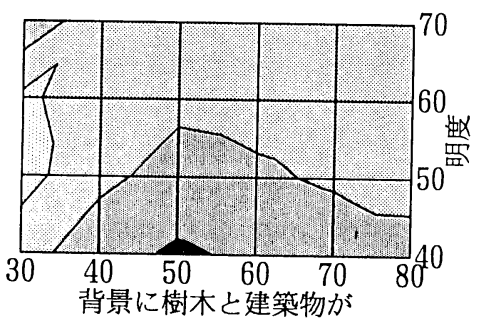

混在した場合の緑化面積率（\%)

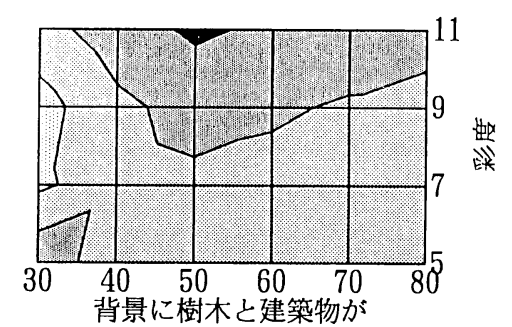

混在した場合の緑化面積率（\%)

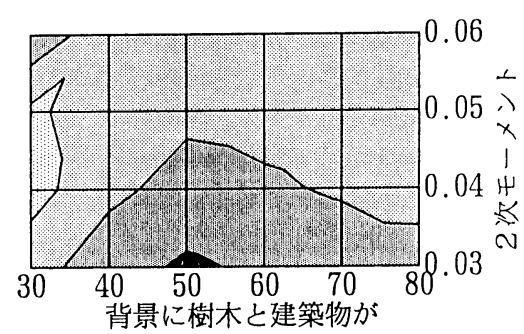

混在した場合の緑化面積率（\%)

平均得点

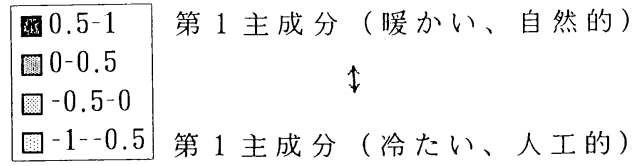


めて難しいことがわかる。しかし, 背景の面積の面積率 が低くなるとこの傾向は一変し, 製品の表面性状を工夫 することにより，あるレベル以上の景観向上を図ること が可能となる。すなわち, 都市部における護岸構造物の 景観設計では, 背景の建築物の面積率の大小に影響を大 きく受け, 大変複雑であることがわかる。

（3）背景が樹木および建築物が混在する場合

図-7 は樹木および建築物が混在する場合の影響を示 すものである。背景が樹木のみの場合, 景観評価は 25 \%の緑化面積率で最も高くなったが, 背景に樹木と建 築物が混在する場合, 景観評価は $50 \%$ の緑化面積率で 高くなった。これは, 背景に「冷たい, 人工的」と感じ る建築物が存在し, それを打ち消すために緑化面積率が 増えたものと考えられる。

4.コンクリート系製品を用いた構造物の 景観設計方法

河川護岸の建設に当たっては, 2. および 3. で明らか にした評洒心理量と物理量との相関性に, 周辺状況の調 查で得られるデーターを適用することによって, 周辺と 調和した構造物を造ることができる。つまりある視点場 から眺めた景観の構成要素を分析し数值化し, その上で 製品表面の物理量との相関関係から製品の選定が可能と なった。たとえば背景に樹木に近似する田園風景が強調 される場合には緑化面積率, 一方背景が都市部の場合に は建築物の面積率および密集状態を数值化すれば, 周辺 と調和する製品の物理量を決めれば良い。景観向上を図 るための構造物に用いる製品の選定のフローの一例を 図一比示す。

\section{1 景観設計のプロセス}

(1) 設計条件の明確化

景観設計は, 策定された景観のマスタープランに従っ て行う。その際建設の基本コンセンサス, 住民および行 政側からの制約, 設計に期待される事項等, 前提条件を 明確にする必要がある。

\section{（2）コンセンサスの設定}

景観評価に最適な形容詞を, 2. で示した製品の表面性 状と相関のある形容詞群の中から選定し, かつそれらの グレードを協議して定め, コンセンサスを得る。

（3）構造物に用いる製品の物理量の選定

景観面の他, 機能性等の条件を考慮して, CG, 合成 写真等で作成した表面性状の複数の写真サンプルの比較 案を作成し，物理量を設定する。それらについて官能検 查を行い，(2) で作成したコンセンサスに見合っている か確認を行う。さらに構造・コストの検討した上, 設計 の最終案として実施に移すことができるであろう。

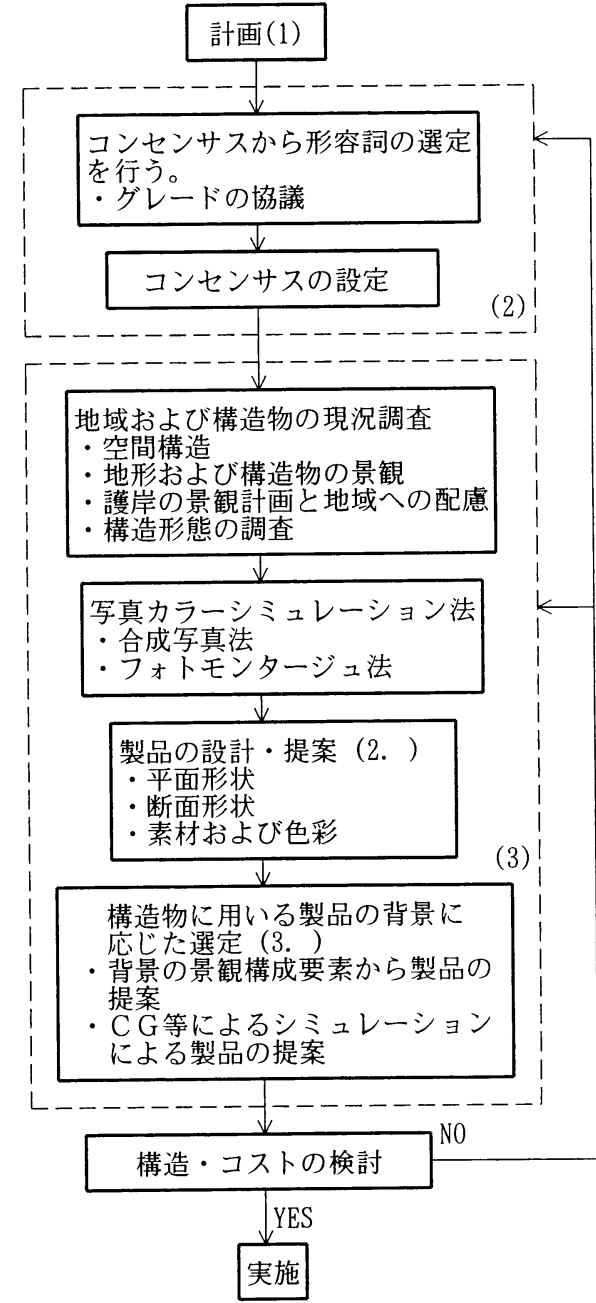

注：（ ）の数值は 4.1 の項目番号を示す。

図-8 景観設計のフローチャート

表-8 官能検查結果

\begin{tabular}{c|c|c}
\hline 形 容 詞 & 原景 $($ 写真 -4$)$ & 修景後 $($ 写真 -5$)$ \\
\hline 自然的な一人工的な & -1.2 & 1.8 \\
\hline
\end{tabular}

\section{2 景観設計の試行例}

河川の修景のための提案例を示す。写真 -4 に示すよ うに, 原景は背景に樹木の山が存在する河川護岸で, コ ンクリートブロックに対する評価は, 冷たい, 污い, 人 工的等マイナスのイメージが強い傾向が認められたもの であった。この場合 [自然的と思う］というコンセンサ スを設定した。図-5に示した相関図を用いて, 背景に 占める樹木の面積率が $70 \%$ の時の製品の物理量, すな わち $L$ (明度) およびC (彩度) の選定を行った。最適 值に最も近い物理量を持った製品として緑化ブロック 


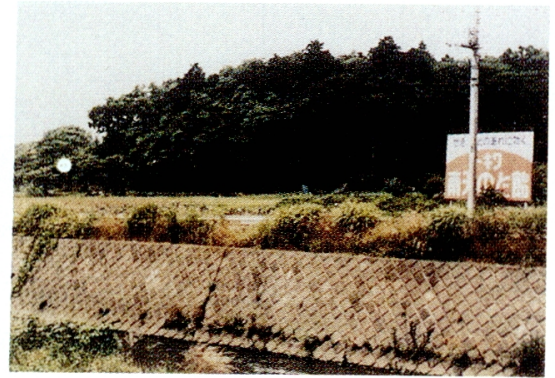

写真 -4 原 景

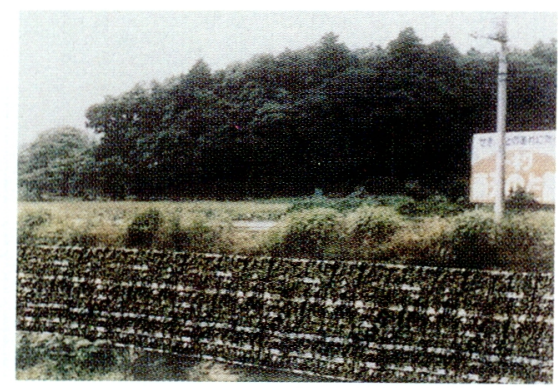

写真-5 修景後のイメージ

( $L=46.62, C=7.81)$ を採用して写真 -5 を得た。

写真 -4 および写真 -5 に対して「自然的な一人工的 な」の形容詞について 5 段階尺度でアンケートした結 果，表-8が得られた。修景することにより [自然的] と思う度合いが強くなる傾向が確かめられた。以上の結 果, 図-8に示すフローは, 周辺環境と調和したコンク リート系製品を検討する一例となり得ることが確認され た。

\section{5. ‡とめ}

本研究は河川護岸構造物に用いるコンクリート系製品 を取り上げて, 周辺環境と調和したコンクリート系製品 の基礎資料を得ることを目的とし, 製品の表面性状の違 いに加え, 製品までの視距離および背景の相違等が評価 心理に及ぼす影響をSD 法による官能検査を実施し，製 品の表面性状との交互作用を定量的に考察した。

本研究の範囲内で得られた結論を要約すると次のよう になる。

（1）コンクリート系製品を用いた河川護岸構造物の 景観評価心理構造は,『暖かさの感覚』および『新しさ の感覚』によってほぼ説明が可能である。
（2）視点から対象物までの距離の影響は, 本実験の 範囲 $(3 \mathrm{~m} \sim 180 \mathrm{~m})$ では，ほとんど見られなかった。

（3）河川護岸構造物のコンクリート系製品を用い て, 周辺環境との調和を図る場合, コンクリート製品の 表面性状への配慮は, 背景が樹木を中心とする緑が支配 的な場合上建築物が支配的な場合では異なるものとな る。すなわち, 背景に緑の占める割合が大きい場合に は, 製品の明度, 彩度, 表面の 2 次モーメントを工夫す ることにより容易に [暖かい]，［自然的］を強調するこ とができるが, 建築物の占める割合が多いと大変難しく なる。

（4）コンクリート系製品を用いた構造物の景観を考 慮した設計のフローチャートとして, 図-8に示すこと ができた。

以上,ここでは主として人間の心理評価を基準にした 景観設計について述べているが, 今後生物学的環境に配 慮する必要がある。

[謝辞］本研究を進めるにあたり，日本セメント株 式会社 藤原浩巳氏, 田中敏嗣氏, 遠藤秀紀氏並びに山 田智恵子さんに御協力戴きました。ここに深く感謝しま す。

\section{参考文献}

1) 田中敏嗣・岡本享久・堀口 剛：セメント系素材を用い た護岸構造物の景観評価, セメント・コンクリート論文 集 No. 47, pp. 665 666, 1993

2）村田茂樹・仕人豊和・田中敏嗣・堀口 剛：景観におけ るセメント系材料の表面テクスチャーと心理構造の相関 に関する研究, 日本建築学会学術梗概講演集, pp. 856 $\sim 861,1993$

3）村田茂樹・仕入豊和・荏本孝久：建築外装材の景観評価 における写真サンプルを用いた官能検查の妥当性, 日本 建築学会学術梗概講演集, pp. 737〜 738, 1994

4）樋渡涓二：画像工学ハンドブック, pp. 236〜243, 朝倉 書店, 1988

5) 田中敏嗣・鳥居南康一・岡本享久 : 景観構成要素がセメ ント系素材を用いた護岸構造物の景観評価に及ぼす影 響, セメント・コンクリート論文集, No. 48,pp. 678〜 683, 1994

6) 金子隆芳：色彩の科学, pp. 194 196, 岩波新書, 1988

7）小柳武和 - 篠原 修 - 田村幸久 - 中村良夫 - 樋口忠彦： 土木工学大系 13 , 景観論, 彰国出版

(原稿受理年月日：1995 年 7 月 10 日) 


\title{
A Fundamental Study on Landscape Design of Bank Protection Structures Using Concrete Manufactures
}

\author{
By Shigeki Murata, Takahisa Okamoto, Koichi Toriiminami and Toyokazu Shiire
}

\author{
Concrete Research and Technology, Vol. 7, No. 1, Jan. 1996
}

Synopsis The authors have been studying the relationships between properties of surface texture on concrete manufactures commonly used in concrete structures and sensory evaluation results, in order to establish reasonable landscape design methods of concrete structures. In the case of discussing about landscape of structures, not only the surface properties of concrete manufactures but also the distance from viewpoint to structures and the background formed structures have direct effects upon the landscape evaluation results.

Keywords : concrete structure, bank protection structure, concrete manufacture, landscape evaluation, surface texture, color, background, landscape design method 